\title{
RESPONS NABI TERHADAP TRADISI JAHILIYYAH: Studi Reportase Hadis Nabi
}

\author{
Abdul Sattar \\ Universitas Islam Negeri Walisongo Semarang \\ e-mail: sattar_semarang@yahoo.co.id
}

\begin{abstract}
This writing aims to study about the dialogue between norm and culture; in this case dialogue between Muhammad as Messenger of God with his people at that time. As we knew that all societies, including Arabic people, absolutely had their own specific tradition. When Muhammad comes to them and offering new norm, ideology and believe, it will appear the dialogue between these two traditions. The question is what is Muhammad do to respond that tradition? This article is based on library research relating to the hadith literature dealing with Muh\}ammad's respond to the tradition of Arabic people. To make the research easier, the word "aljāhiliyyah" will be used as an entry point to look for jāhiliyyah tradition. The are four important things can be noted to explain the response of Muh\}ammad to the tradition of jāhiliyyah. The first, total accommodation. The second, total refuse or total correction. The third, particular accommodation. The fourth, synchronization and modification.
\end{abstract}

\begin{abstract}
Abstrak: Penelitian ini bermaksud mengkaji tentang dialog agama dan budaya; dalam hal ini dialog antara Nabi Muhammad dengan budaya masyarakat Arab jahiliyyah saat itu. Sebuah masyarakat, termasuk masyarakat Arab sebelum kedatangan Islam, bukanlah masyarakat yang steril dari pengaruh agama, adat istiadat, akhlak serta peraturan-peraturan hidup yang telah ada di kalangan mereka. Begitu Islam datang dengan segala norma yang ada di dalamnya, maka Islam menjadi filter bagi budaya, adat istiadat dan keyakinan yang sudah ada di kalangan masyarakat Aran pra Islam. Pertanyaannya adalah bagaimana respon Muh\}ammad saw terhadap tradisi itu? Kajian ini didasarkan pada penelitian literatur hadìth yang berisi respon Nabi terhadap tradisi masyarakat Arab saat itu. Untuk memudahkan pembahasan ini, kata "al-jāhiliyyah" digunakan sebagai entri point guna melacak hadis-hadis yang berkenaan dengan tema kajian ini. Ada empat temuan penting yang bisa dicatat berkenaan dengan respon Nabi terhadap tradisi jāhiliyyah. Pertama, tradisi yang secara utuh diakomodasi (total accomodation). Kedua, tradisi yang secara total ditolak atau total dikoreksi (total refuse or total correction). Ketiga, tradisi yang sebagiannya diadopsi tetapi sebagian yang lain ditolak (particular accomodation). Keempat, tradisi yang secara prinsip tetap dilestarikan dengan sedikit modifikasi di sana-sini (sincronization and modification).
\end{abstract}

Keywords: jahiliyyah; tradisi; respons Nabi; adopsi; akomodasi 


\section{A. Pendahuluan}

Membahas tentang "Respons Nabi terhadap Tradisi Jahiliyyah: Studi Repostase Hadīs Nabi" sebagaimana tema tulisan ini, maka setidaknya ada empat hal penting yang perlu dipahami terlebih dahulu, yaitu: respons, tradisi, jahiliyyah dan hadis.

Respons yang dimaksud dalam tulisan ini adalah "act in answer to some thing"1, yaitu hal yang dilakukan guna menjawab sesuatu. Bila berkenaan dengan tema tulisan ini, maka yang dimaksud adalah apa yang dilakukan Nabi berkenaan tradisi jahîliyyah yang sudah ada sebelum Islam datang.

Jika dalam tulisan ini disebutkan kata tradisi, maka yang dimaksudkan adalah segala bentuk pengetahuan, doktrin, kebiasaan, praktek dan lain-lain yang diwariskan turun temurun termasuk cara penyampaian pengetahuan, doktrin dan praktek tersebut. ${ }^{2}$ Jadi, jika tertulis tradisi jahliyyah maka yang dimaksudkan adalah segala bentuk pengetahuan, doktrin, kebiasaan, praktek dan lain-lain yang diwariskan turun temurun termasuk cara penyampaian pengetahuan, doktrin dan praktek tersebut oleh masyarakat jahiliyyah.

Kata "jāhiliyyah" yang secara Bahasa Arab berarti kedobohan, yang disematkan kepada kaum musyrikin sebelum datang Islam adalah terma yang merangkum keseluruhan makna penyelewengan dalam beribadah, kezaliman dan pembangkangan terhadap kebenaran. Jahiliyah terbesar adalah penyembahan kepada selain Allah atau syirik. Ia adalah ciri paling dominan untuk kata jahiliyah. Karena itu, masa sebelum pengutusan yang bergelimang kesyirikan disebut jaman jahiliyah.

Pada asalnya kata jahiliyyah merujuk pada makna kondisi bangsa Arab pada periode pra-Islam. Kondisi yang diliputi kebodohan tentang Allah, RasulNya, syariat agama, berbangga-bangga dengan nasab, kesombongan dan sejumlah penyimpangan lainnya. Namun jahiliyah juga bisa berupa sifat yang ada pada seseorang yang sudah memeluk Islam. Jahiliyah dengan makna ini ditunjukkan oleh sabda Rasul yang berbunyi.

1Martin H. Manser, Oxford Learner's Pocket Dictionary (New York: Oxford University Press, 1991), h. 353.

2Dikutip dari Muhaimin AG, Islam dalam Bingkai Budaya Lokal: Potret Dari Cirebon (Ciputat: PT.Logis Wacana Ilmu, 2001), h.11. 


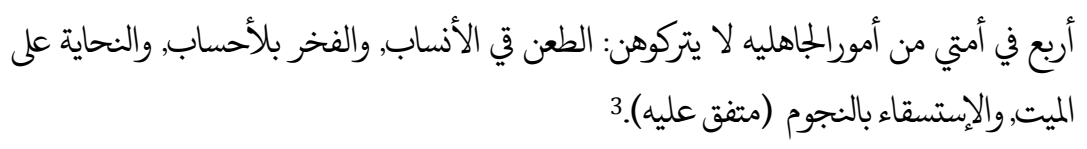

"Empat hal pada umatku dari perkara jahiliyah yang mereka tidak meningalkannya: mencela nasab, menyombongkan keturunan/leluhur, meratapi mayyit dan meminta hujan kepada bintang-bintang."

Dalam konteks makna jahiliyah yang dalam Bahasa Arab berasal dari suku kata الجكل secara sederhana berarti kebodohan atau tidak adanya ilmu. Ṣālih alFauzān menegaskan bahwa yang dimaksud dengan jahiliyyah adalah kebodohan karena tidak ada Rasul dan kitab. Dengan demikian yang dimaksud adalah keadaan sebelum diutusnya Nabi karena sebelum diutusnya Nabi Muhammad, dunia berada dalam kesesatan, kekufuran dan penyimpangan. Hal ini dikarenakan risalah-risalah sebelumnya telah musnah. Yahudi menyimpangkan kitab mereka yaitu Taurat dan demikian juga Nasrani menyimpangkan kitab Injil. Jadi, tambah Ṣāliḥ al-Fauzān, mengartikan jahiliyah dengan kebodohan semata-mata kurang tepat, apalagi mengartikan dengan kebodohan terhadap teknologi dan ilmu pengetahuan. ${ }^{4}$

Karen Amstrong dalam bukunya Sejarah Islam menegaskan bahwa jahiliyah adalah barbarisme masa pra Islam yang senantiasa menjadi musuh bagi keimanan. Dalam historiografi Muslim konvensional, jahiliyah digunakan untuk menunjukkan periode pra Islam di Arab. ${ }^{5}$

Dengan gambaran tersebut, maka jahiliah adalah kata untuk seluruh perkara yang bertentangan dengan ajaran Islam, baik pelanggaran besar yang berakibat kekafiran atau pelanggaran kecil yang tidak berakibat kekafiran. Semuanya dikatakan jahiliyah karena seluruh pelanggaran atau perkara yang bertentangan dengan ajaran Islam tidak mungkin bersumber dari ilmu, melainkan dari kebodohan. Baik pelanggaran itu disebabkan karena ketidaktahuan atau karena dominasi hawa nafsu yang mengalahkan dorongan keimanan.

Dalam al-Qur'an, kata jahiliyah disebutkan Allah sebanyak empat kali. Masing-masing disebutkan dalam konteks sebagai sebuah keyakinan, sistem,

3HR. Bukhari: hadīs no.3851, Muslim: hadīs no. 934.

4Ṣālih al-Fauzān, Syarḥ Masā’il al-Jāhiliyyah (Mesir: Dār al-Bașīrah, 1997), h. 8-12.

${ }^{5}$ Karen Amstrong, Sejarah Islam: Telaah Ringkas-Komprehensif Perkembangan Islam Sepanjang Zaman, terj. Yuliani Liputo (Bandung: Mizan, 2014), h. 237-238. 
perilaku dan watak. ${ }^{6}$ Untuk lebih jelas, kita akan uraikan ayat-ayat tersebut satu persatu.

Pertama, keyakinan.

Allah berfirman,

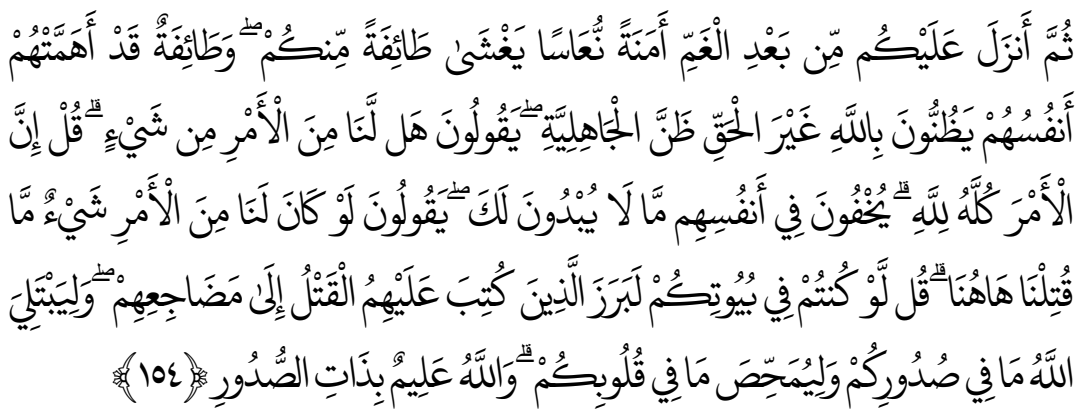

"Kemudian setelah kamu berduka-cita Allah menurunkan kepada kamu keamanan (berupa) kantuk yang meliputi segolongan daripada kamu, sedang segolongan lagi telah dicemaskan oleh diri mereka sendiri; mereka menyangka yang tidak benar terhadap Allah seperti sangkaan jahiliah. Mereka berkata: "Apakah ada bagi kita barang sesuatu (hak campur tangan) dalam urusan ini?" Katakanlah: "Sesungguhnya urusan itu seluruhnya di tangan Allah". Mereka menyembunyikan dalam hati mereka apa yang tidak mereka terangkan kepadamu; mereka berkata: "Sekiranya ada bagi kita barang sesuatu (hak campur tangan) dalam urusan ini, niscaya kita tidak akan dibunuh (dikalahkan) di sini". Katakanlah: "Sekiranya kamu berada di rumahmu, niscaya orang-orang yang telah ditakdirkan akan mati terbunuh itu ke luar (juga) ke tempat mereka terbunuh". Allah (berbuat demikian) untuk menguji apa yang ada dalam dadamu dan untuk membersihkan apa yang ada dalam hatimu. Allah Maha Mengetahui isi hati." (QS. Ali 'Imran: 154)

Dalam ayat ini, Allah merekam cuplikan peristiwa yang pernah terjadi pada masa Rasulullah bersama para sahabat. Persisnya pada saat kegentingan perang yang akan dihadapi oleh kaum Muslimin. Perang yang akan mereka hadapi adalah perang Uhud, perang besar kedua setelah perang Badar Kubra, dimana umat Islam menderita kekalahan. Kekalahan yang terjadi pada saat perang Uhud

\footnotetext{
${ }^{6}$ https://sabilulilmi.wordpress.com/2013/01/17/jahiliyyah-dalam-al-quran/. diakses pada Minggu 1 Mei 2016.
} 
ini, kata Syeikh Muḥammad Abduh, lebih diakibatkan karena sebagian umat Islam pada saat itu merasa lemah, ragu-ragu dan sangat tidak percaya diri sehingga membuat mereka gagal dan melanggar instruksi Nabi Muhammad. ${ }^{7}$

Zan al-Jāhiliyyah, atau prasangka jahiliah yang terdapat dalam ayat ini digunakan untuk mewakili suatu kondisi keyakinan, yaitu keyakinan yang lemah, dangkal dan dipenuhi keraguan. Secara lebih detail, Quraish Shihab menjelaskan bahwa yang dimaksud dengan zan al-jāhiliyyah adalah nilai-nilai yang bertentangan dengan nilai-nilai ajaran Islam seperti mereka yang tidak mengetahui bahwa apa yang dikendaki Allah pasti terjadi dan apa yang tidak dikehendakiNya tidak akan terjadi. Mereka berkata sambil menggerutu ".... Kami tidak bersalah dan tidak bertangung jawab sedikit pun menyangkut petaka ini, bahkan Nabi saw tidak mendengar saran kami agar jangan keluar dari Madinah".

Salah satu bentuk sangkaan jahiliyah (zan al-Jāhiliyyah) yang boleh jadi terbetik dalam benak sementara orang, termasuk yang terlibat dalam perang Uhud, adalah dugaan bahwa kemenangan akan diperoleh tanpa usaha, cukup dengan nama Islam yang mereka sandang, dan bahwa agama yang benar, pasti menang walau tidak diperjuangkan. Atau, bahwa kemenangan pasti diraih karena seorang agung semacam Nabi Muhammad berada bersama mereka. Ini semua, tambah Quraish Shihab, adalah jenis-jenis sangkaan jahiliyah yang mengabaikan sunnatullāh, prinsip sebab dan akibat, bahkan melupakan bahwa bantuan Ilahi, baru hadir jika upaya maksimal manusia telah dilakukan. ${ }^{9}$

Kedua, sistem hukum.

Allah berfirman,

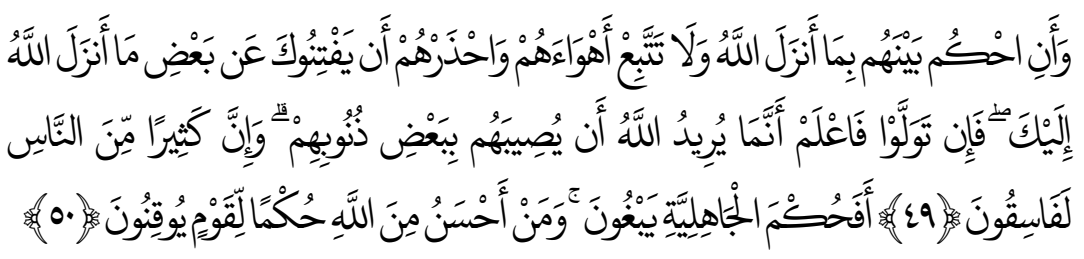

7Muhammad Abduh, Tafsīr al-Qurān al-H\{akīm al-Masyhūr bi al-Tafsīr al-Manār (Beirūt: Dār al-Fikr, t.th.), Jilid IV, h. 186.

${ }^{8}$ M. Quraish Shihab, Tafsir al-Mishbah: Pesan, Kesan dan Keserasian al-Quran (Ciputat: Lentera Hati, 2012), h. 301-304.

9lbid., 
"Dan hendaklah kamu memutuskan perkara di antara mereka menurut apa yang diturunkan Allah, dan janganlah kamu mengikuti hawa nafsu mereka. Dan berhati-hatilah kamu terhadap mereka, supaya mereka tidak memalingkan kamu dari sebahagian apa yang telah diturunkan Allah kepadamu. Jika mereka berpaling (dari hukum yang telah diturunkan Allah), maka ketahuilah bahwa sesungguhnya Allah menghendaki akan menimpakan musibah kepada mereka disebabkan sebahagian dosa-dosa mereka. Dan sesungguhnya kebanyakan manusia adalah orang-orang yang fasik. Apakah hukum Jahiliah yang mereka kehendaki, dan (hukum) siapakah yang lebih baik daripada (hukum) Allah bagi orang-orang yang yakin?" (QS. al-Maidah: 49-50)

Ayat ini menerangkan perintah Allah dalam menegakkan sistem hukum yang telah Allah turunkan bagi segenap manusia di muka bumi. Hukum Allah adalah hukum yang paripurna dan paling adil. Tidak ada keadilan kecuali jika hukum Allah diterapkan bagi segenap kehidupan manusia di dunia. Selain hukum Allah, tidak ada hukum yang akan sanggup menciptakan kemakmuran, kesejahteraan dan keharmonisan bagi seluruh makhluk yang hidup di atas muka bumi ini.

Perintah untuk melaksanakan hukum Allah, dalam ayat ini Allah lanjutkan dengan larangan mengikuti hawa nafsu. Ini artinya, bahwa selain hukum Allah, apa pun bentuknya, adalah hukum dan aturan yang berdasarkan hawa nafsu manusia. Hukum-hukum yang diciptakan dengan reka-reka akal manusia bukan hukum yang menjamin kehidupan yang baik di dunia, terlebih lagi di akhirat kelak. Semua hukum itu sesat dan sangat jauh dari kebenaran. Allah berfirman, "... maka tidak ada sesudah kebenaran itu, melainkan kesesatan"(QS. Yunus: 32).

Sistem hukum selain milik Allah sebagaimana dinyatakan dalam Surat alMāidah: 50 disebut Allah sebagai hukm al-jāhiliyyah atau sistem hukum jahiliyah. Muhammad Husein al-Ṭabațabai menjeskan bahwa yang dimaksud dengan hukum jahiliyah adalah sistem hukum yang disusun berdasarkan hawa nafsu. Orang-orang yang berpaling dari hukum Allah kemudian menjadikan hukum jahiliyah sebagai panglima, sebenarnya apa yang mereka inginkan?10

Bagi orang-orang yang bertauhid bersih dan beriman kuat, sistem hidup yang Allah letakkan adalah sistem yang paling baik. Mereka tidak menginginkan

${ }^{10}$ Muhammad Husein al-Ṭabațaba'i, al-Mīzān fi Tafsìr al-Qurān (Libanon: Muassasah al-A'lā li al-Mațbūāt, 1991), Juz. V, h. 364-365. 
hukum selain yang Allah turunkan. Mereka tidak alergi dengan hukum itu apalagi sampai membenci, memerangi dan menjegal penerapannya. Karena ketundukan yang diperolehnya dari rasa iman dan tauhid yang telah mengkristal itulah mereka sangat percaya menggantungkan semua hidupnya diatur oleh Allah yang Mahatahu, Maha Berkuasa dan Maha Bijaksana.

Ketiga, perilaku.

Allah berfirman,

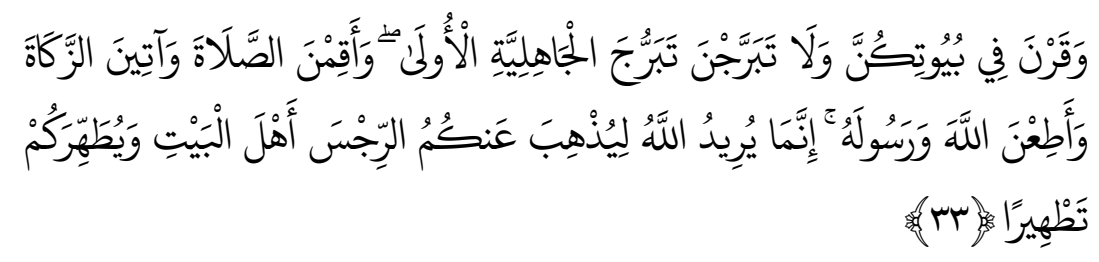

"Dan hendaklah kamu tetap di rumahmu dan janganlah kamu berhias dan bertingkah laku (tabarruj) seperti orang-orang Jahiliyah yang dahulu dan dirikanlah salat, tunaikanlah zakat dan taatilah Allah dan Rasul-Nya. Sesungguhnya Allah bermaksud hendak menghilangkan dosa dari kamu, hai ahlul bait dan membersihkan kamu sebersih-bersihnya." (QS. al-Ahzab: 33)

Ayat ini melarang para wanita kamu Muslimin untuk berhias dan bertingkah laku (tabarruj) seperti orang-orang jahiliah. Wanita jahiliah adalah wanita yang tidak mengenal kesopanan dalam berpakaian, bertingkah laku dan bergaul dengan lawan jenis. Karena tingkah laku yang tanpa aturan itu, fahisyah dan kemungkaran tersebar di mana-mana.

Islam kemudian datang dengan sejumlah aturan yang membatasi pergaulan dan interaksi kaum wanita. Demi keseimbangan sosial dan kenyamanan hidup bermasyarakat, etika pergaulan ini Allah tetapkan agar ketimpangan dan keserawutan hidup bisa dicegah dan ditanggulangi. Tentu saja sejumlah aturan ini bukan untuk memasung kebebasan dan mengerangkeng hak-hak hidup manusia.

Persoalan interaksi tidak bisa berjalan dengan bebas aturan dan sekehendak hati. Proses interaksi yang kondusif dan benilai positif adalah akumulasi dari perilaku masyarakat yang tertib, bertanggungjawab dan mengindahkan norma-norma pergaulan. Tanpa hal itu, ketentraman hidup yang menjadi cita-cita bersama akan sulit dipertahankan. 
Khusus mengenai proses interaksi antara laki-laki dan perempuan, ini termasuk salah satu bentuk interaksi yang mesti diatur. Larangan khalwah, ikhtilāt dan berzina serta perintah untuk menjaga pandangan ( ghaḍ al-bașar), menutup aurat dan menikah adalah seperangkat etika yang berprinsip menjunjung moralitas dan ketertiban.

Keempat, watak.

Allah berfirman,

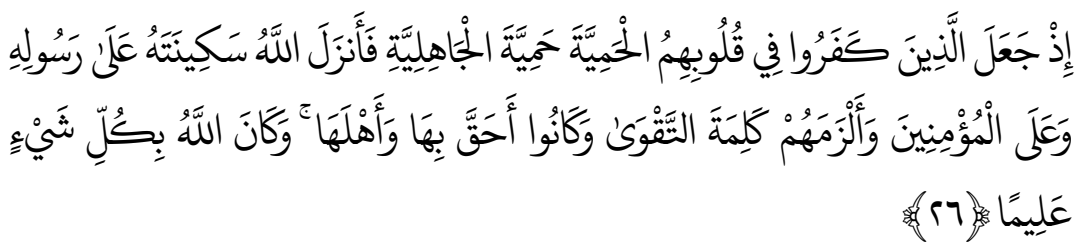

"Ketika orang-orang kafir menanamkan dalam hati mereka kesombongan (yaitu) kesombongan (hamiyyah) jahiliah lalu Allah menurunkan ketenangan kepada Rasul-Nya, dan kepada orang-orang mukmin dan Allah mewajibkan kepada mereka kalimat takwa dan adalah mereka berhak dengan kalimat takwa itu dan patut memilikinya. Dan adalah Allah Maha Mengetahui segala sesuatu." (QS. al-Fath: 26)

Ayat ini turun menanggapi sikap kaum musyrikin Quraisy dalam peristiwa perjanjian Hudaibiyyah. Mereka menolak Nabi dan rombongan para sahabat sebanyak tujuhratus orang memasuki Mekkah untuk melaksanakan umrah pada tahun itu. Mereka juga menolak kalimat "bismillāhi al-raḥmān al-rahīm" saat akan dituliskan dalam lembar perjanjian. Namun kaum Muslimin saat itu diberikan Allah ketenangan. Mereka bersabar dan tidak terbawa emosi. Mereka tetap mematuhi ketentuan Allah.

Ayat ini menggambarkan kondisi hati kaum Musyrikin yang dipenuhi watak kesombongan dan fanatisme kelompok. Reputasi semu kesukuan yang mereka banggakan membuatnya merasa tidak pantas memakai sesuatu di luar tradisinya. Sikap pembelaan atas dasar kelompoknya telah membutakan hati mereka dari kebenaran. Itulah kaum musyrikin Quraisy dulu yang sombong, angkuh dan keras kepala. Watak buruk itulah yang menghalangi sampainya hidayah dan ilmu kepada mereka.

Padahal kebenaran telah jelas bagi mereka. Sama sekali mereka tidak dapat mematahkan argumentasi kebenaran Islam. Justru Islam membeberkan kepada 
mereka bahwa landasan kebenaran yang mereka yakini itu tidak berdaya, lemah dan dangkal. Sangat tidak pantas bila keyakinan yang berdasar pada pijakan yang rapuh itu masih diikuti, dibela, diperjuangkan dan dipertahankan dengan membabi-buta. ${ }^{11}$

Gambaran tersebut menjadi bukti yang meyakinkan bahwa sebuah masyarakat, termasuk masyarakat Arab sebelum kedatangan Islam, bukanlah masyarakat yang steril dari pengaruh agama, adat istiadat, akhlak serta peraturan-peraturan hidup yang telah ada di kalangan mereka. Bahkan beberapa bentuk keyakinan, sistem hukum, perilaku dan watak yang mereka miliki sesungguhnya menjadi bagian yang melekat pada mereka. Oleh karena itu, pada saat Islam datang kepada masyarakat Arab pra Islam, maka sudah barang tentu akan terjadi "dialog" antara Islam dengan apa yang sudah ada dan hidup di tengah-tengah mereka.

Pertanyaannya adalah bagaimana "nasib" dari tradisi yang hidup sebelum Islam datang? Bagaimana respon Islam dengan tradisi tersebut? Apakah secara otomatis tradisi itu diadopsi oleh Islam secara utuh atau diadopsi oleh Islam dengan filterisasi disana sini? Pertanyaan-pertanyaan inilah yang akan dijawab dalam kajian ini dengan menggunakan perspektif reportase hadis Nabi.

Bila dalam tulisan ini disebutkan terma hadis, maka yang dimaksud adalah 'segala sesuatu yang disandarkan kepada Nabi baik berupa perkataan (qawl), perbuatan (fi'), ketetapan (taqrīr) dan hal ikhwal (sifat dan keadaan) Nabi. ${ }^{12}$

Dengan demikian, maka yang diinginkan dalam tulisan ini adalah respon Nabi baik berupa perkataan (qawl), perbuatan (fi't), ketetapan (taqrīr) dan hal ikhwal (sifat dan keadaan) Nabi berkenaan dengan pengetahuan, doktrin, kebiasaan, praktek dan lain-lain yang diwariskan turun temurun termasuk cara penyampaian pengetahuan, doktrin dan praktek tersebut oleh masyarakat sebelum Islam.

\section{B. Fokus dan Tujuan Kajian}

Tulisan ini akan berusaha menjawab pertanyaan bagaimana respon Nabi terhadap tradisi jahiliyyah yang ada pada masyarakat Arab sebelum kedatangan

\footnotetext{
${ }^{11}$ Ibid.

12Muhammad Musțafā Azami, Studies in H\{adith Methodologi and Literature (Indanapolis: Islamic Teaching Centre, 1977), h. 1-2
}

JURNAL THEOLOGIA — Volume 28, Nomor 1, Juni 2017 
Islam. Untuk mengurai hal ini, maka setidaknya ada tiga hal yang bisa dilalui. Pertama, mengetahui jenis tradisi yang hidup di kalangan masyarakat Arab sebelum hadirnya Islam. Kedua, mengetahui "proses dialog" yang terjadi antara tradisi masyarakat Arab Jahiliyyah dengan tradisi Islam yang hadir di tengahtengah mereka. Ketiga, mengetahui bentuk reportase hadith yang menggambarkan respon Nabi terhadap tradisi tersebut.

\section{Telaah Pustaka}

Banyak sekali karya-karya yang ditulis berkenaan dengan kajian tentang tradisi masyarakat Arab pra Islam. Beberapa diantara karya yang dimaksud adalah karya Muḥammad Sa'îd Ramaḍān al-Buti yang sudah diterjemahkan ke dalam Bahasa Indonesia dengan judul Sirah Nabawiyah: Analisis Ilmiah Manhajiah, sejarah pergerakan Islam di masa Rasūlullah. Saîd Ramaḍān menjelaskan bahwa salah satu corak beragama yang ada sebelum Islam datang adalah Haniffiyah, yaitu sekelompok orang yang mencari agama Ibrahim yang murni yang tidak terkontaminasi oleh nafsu penyembahan berhala-berhala, juga tidak menganut agama Yahudi ataupun Kristen, tetapi mengakui keesaan Allah. Mereka berpandangan bahwa agama yang benar di sisi Allah adalah Hanifiyah, sebagai aktualisasi dari millah Ibrahim. Gerakan ini menyebar luas ke pelbagai penjuru Jazirah Arab khususnya di tiga wilayah hijaz, yaitu Yathrib, Taif, dan Mekah. Di antara mereka adalah Rāhib Abū 'Ámir, Umayyah bin Abī al-Ṣalt, Zayd bin 'Amr bin Nufayl, Waraqah bin Nawfal, 'Ubaydullāh bin Jaḥs, Ka'ab bin Lu’ay, 'Abd al-Mutallib, 'As'ad Abū Karb al-Ḥamīrī, Zuhayr bin Abū Salma, 'Uthmān bin al-Huwayrith. 13

Tradisi-tradisi warisan mereka yang kemudian diadopsi Islam adalah: penolakan untuk menyembah berhala, keengganan untuk berpartisipasi dalam perayaan-perayaan untuk menghormati berhala-berhala, pengharaman binatang sembelihan yang dikorbankan untuk berhala-berhala dan penolakan untuk memakan dagingnya, pengharaman riba, pengharaman meminum arak dan penerapan vonis hukuman bagi peminumnya, pengharaman zina dan penerapan vonis hukuman bagi pelakunya, berdiam diri di gua hira sebagai

\footnotetext{
${ }^{13}$ Muhammad Sa’̂̀d Ramaḍān al-Buti, Sirah Nabawiyah, Analisis Ilmiyah Manhajiah, Sejarah Pergerakan Islam dimasa Rasulullah, terj. AunurRafiq Saleh Tamhid (Jakarta: Robbani Press, 2005), h. 21.
} 
ritual ibadah di bulan ramaḍan dengan memperbanyak kebajikan dan menjamu orang miskin sepanjang bulan ramadan, pemotongan tangan pelaku pencurian, pengharaman memakan bangkai, darah, dan daging babi, dan larangan mengubur hidup-hidup anak perempuan dan pemikulan beban-beban pendidikan mereka. ${ }^{14}$ Karya ini tidak berupaya mengemukakan kajiannya berdasarkan hadis Nabi, tetapi lebih merujuk pada kitab-kitab tārīkh (sejarah).

Karya lain yang mencoba mengemukakan tradisi jahiliyyah adalah tulisan Syafiq A. Mughni dalam Ensiklopedi Tematis Dunia Islam. Dalam tulisannya, Syafiq A. Mughni menjelaskan bahwa selain dunia kesusastran masyarakat pra Islam pada saat itu telah memiliki sistem hukum yang berlaku. Diantaranya adalah sistem pewarisan, perkawinan dan perceraian. Khusus masalah perkawinan terdapat bentuk-bentuk perkawinan yang mereka jalankan diantaranya adalah: perkawinan mut'ah (kesenangan), perkawinan zawāq (cicipan), perkawinan istibda' (menjadikan barang dagangan), perkawinan khadn (teman intim), perkawinan mutaḍāmidah (saling membalut), perkawinan badal (tukar), perkawinan șighār (liar), perkawinan maqt (kutukan), perkawinan saby (tawanan), perkawinan hamba sahaya, perkawinan antara saudara lelaki dan saudara wanitanya, atau ayah dan putrinya, perkawinan dengan beberapa istri bahkan hingga berpuluh-puluh orang dalam satu masa serta perkawinan bu'ülah (suami/istri) atau ahadi (monogami).15 Tulisan Syafiq A. Mughni ini cukup banyak memberikan informasi mengenai tradisi yang hidup di kalangan masyarakat Arab pra Islam. Selain bidang sastra dan hukum, ada kebiasaan sosial masyarakat Arab yang juga dielaborasi, seperti al-qimār (judi), minum khamar, membunuh anak perempuan hidup-hidup, menjajakan para budak sebagi pelacur dan beberapa kebiasaan lainnya. ${ }^{16}$ Namun, Syafiq A. Mughni belum berupaya mengelaborasi hadis-hadis yang menggambarkan tradisi tersebut.

Ada lagi tulisan yang berkenaan dengan tradisi masyarakat Arab pra Islam yang di kemudian hari tradisi itu juga diadopsi oleh Islam. Dalam hal ibadah misalnya, kata Abdul Karim, Islam menjalankan ibadah haji dan umrah

${ }^{14}$ Ibid.; Lihat juga http://msubhanzamzami.wordpress.com/2010/10/18/kondisi-Arab-praIslam-dalam-aspek-sosial-budaya-agama-ekonomi-dan-politik/, lihat juga dalam laman http:// msubhanzamzami.wordpress.com. Diakses pada tanggal 28 April 2016. 24.

${ }^{15}$ Syafiq A. Mughni, Ensiklopedi Tematis Dunia Islam (Jakarta: Ichtiar Baru Van Hoeve), h. 23-

${ }^{16}$ Ibid., h. 25. 
sebagaimana telah dipraktekkan dalam masyarakat Arab jauh sebelum Islam datang. Masyarakat Arab menjalankan ritual-ritual tersebut sebagaimana dijalankan oleh umat Islam sekarang ini, yaitu: talbiyyah, ihrām, wukuf dan lain sebagainya. Setelah kedatangan Islam, kemudian praktek tersebut diteruskan dengan penggunaan istilah yang sama. Akan tetapi Islam kemudian membersihkan ibadah ini dari perilaku syirik. Salah satu yang dibersihkan itu adalah talbiyyah mereka yang semula masih bernuansa syirik. Di samping itu Islam juga melarang bertawaf secara telanjang. ${ }^{17}$

Selain dalam hal ibadah, Ratno Lukito dalam bukunya Islamic Law and Adat Encounter: The Experience of Indonesia yang sudah diterjemahkan dalam Bahasa Indonesia dengan judul Pergumulan antara Hukum Islam dan Adat di Indonesia menjelaskan bahwa hukum Islam juga mengadopsi budaya yang lain, misalnya sistem qisas dan diyat. Kedua hal tersebut merupakan praktek budaya masyarakat pra-Islam kemudian diadopsi dalam hukum pidana Islam. ${ }^{18}$

Ada tulisan menarik dari yang diposting oleh Sholihin Ichin mengenai kebiasaan baik dalam masyarakat jahiliyah yang kemudian dikukuhkan dalam Islam. Diantara sifat-sifat tersebut adalah sebagai berikut: Pertama, jujur. Sifat mulia ini telah dikenal masyarakat Arab sebelum datangnya Islam. Setelah itu, datanglah Islam yang mengukuhkannya.

Kedua, menjamu tamu. Mereka memberi makan kepada tamu yang datang. Hal ini termasuk tanda kedermawanan yang membuat pelakunya terpuji. Islam pun datang untuk menguatkan, sebagaimana sabda Rasulullah, "Barangsiapa yang beriman kepada Allah dan hari kiamat, hendaklah memuliakan tamunya."

Ketiga, menepati janji. Masyarakat Arab membiasakan diri tepat janji dan pantang merusaknya meskipun terkadang harus mengorbankan harta. Ini merupakan akhlak yang mulia. Islam pun mengukuhkan sifat ini dengan firman Allah, “... Orang-orang yang menepati janji apabila berjanji..." (QS. Al-Baqarah: 177)

Keempat, menghormati tetangga, melindungi orang yang meminta perlindungan darinya, tidak pernah mengingkarinya dalam kondisi apapun.

${ }^{17}$ Abdul Karim, Sejarah Pemikiran dan Peradaban Islam (Yogyakarta: Pustaka Book Publisher, 2009), h. 7-8.

${ }^{18}$ Ratno Lukito, Pergumulan Antara Hukum Islam dan Adat di Indonesia (Jakarta: Seri INIS XXXV, INIS, 1998), h. 5-6. 
Dalam sebuah hadits disebutkan, "Kami telah menolong orang yang engkau tolong, wahai Ummu Hani." Kaum Muslimin telah melindungi Abu al-'Ash bin Rabi' -padahal ia orang musyrik- sampai ia memasuki kota Madinah untuk mengambil titipan dan hartanya, kemudian kembali ke Makkah. Sedang beberapa hari, ia pun masuk Islam.

Kelima, sabar dan tahan uji. Masyarakat Arab terbiasa dengan ujian, hingga mereka pun berkata, "Seorang wanita meredeka sedang lapar. Meskipun demikian, ia tidak memakan kedua payudaraku." Islam pun datang dan mengukuhkan sifat-sifat mulia ini. Allah berfirman, "... Bersabarlah kamu dan kuatkanlah kesabaranmu..." (QS. Ali Imran: 200) dan Rasulullah bersabda, "Barang siapa bersabar, ia pasti meraih kesuksesan."

Keenam, pemberani, pantang mundur, dan menjaga harga diri. Masyarakat Arab paling tidak suka dihina dan direndahkan. Inilah yang menjadikan mereka istimewa dari yang lain, baik laki-laki maupun perempuan. Hal ini dibuktikan dalam kisah dan syair-syair mereka.

Ketujuh, menghormati tempat dan bulan yang dimuliakan. Hal ini mereka lakukan dengan cara tidak berperang dalam waktu dan tempat tersebut, kecuali dalam keadaan terpaksa. Mereka juga selalu menjamin keamanan para pendatang yang mengunjungi tanah haram meskipun mereka memiliki masa lalu yang buruk.

Kedelapan, sifat-sifat lain. Selain itu, masyarakat jahiliyah juga memiliki kebiasaan: mereka mengharamkan menikahi ibu dan anak perempuan sendiri, mereka membiasakan mandi jinabat, mereka membiasakan berkumur dan istinsyaq, bersiwak, bersuci, memotong kuku, dan mencabut bulu ketiak, berkhitan untuk anak laki-laki dan khufadh (mengurangi) untuk anak perempuan, memotong tangan kanan bagi pencuri, haji dan umrah. Dalam sebuah kisah, Abu Sufyan bin Harb saat menghadap Herakliun, penguasa Romawi di Syam, yang menanyai Nabi. Abu Sufyan tidak menyembunyikan sedikit pun hal-hal yang ditanyakan kepadanya. Padahal, waktu itu dia masuk musyrik dan masih dalam memerangi Islam. ${ }^{19}$

Sayang sekali bahwa tulisan tersebut sama sekali tidak mencantumkan satu pun literatur yang digunakan sebagai referensi tulisannya. Mei 2016.

19 http://cintarosul.org/kebiasaan-baik-dalam-masyarakat-jahiliyah/. diakses pada Minggu 1 
Ada tulisan menarik dari Toshihiko Izutsu dalam buku "Ethico-Religious Concept In The Quran" mengenai kebajikan masyarakat Arab. Buku yang sudah diterjemahkan menjadi "Etika Beragama Dalam Quran" ini mengemukakan tradisi kebajikan itu dalam uraian sepanjang 54 halaman. Toshihiko Izutsu merangkum setidaknya ada lima kebajikan masyarakat Arab yang kemudian mengalami islamisasi. Kelima kebajikan tersebut meliputi kemurahan hati, keberanian, kesetiaan, kejujuran dan kesabaran. Toshihiko Izutsu memaparkan analisis yang komprehenship dan meyakinkan mengenai kelima tradisi ini sebagai tradisi kebajikan yang kemudian diadopsi oleh Islam. Namun, sesuai dengan judul bukunya, sajian Toshihiko Izutsu dilakukan dalam bingkai perspektif ayat-ayat al-Quran. ${ }^{20}$

Bila dicermati dengan seksama, literatur yang membahas mengenai tradisi masyarakat Arab pra Islam, setidaknya sampai proposal ini ditulis, belum ditemukan kajian yang secara khusus disusun berdasarkan reportase hadis Nabi. Hasil kajian ini nantinya diharapkan menjadi pengisi kekosongan itu.

\section{Metode Kajian}

Jenis kajian ini adalah kajian literer (library research) karena sumber pokok dalam kajian ini adalah karya berupa kitab-kitab hadis. Oleh karena itu, untuk kepentingan kajian ini, data akan dilacak dari 9 kitab hadis rujukan, yaitu Șaḥịh Bukhārī, Șahịḥ̣ Muslim, Sunan Abū Dawud, Sunan Turmudhī, Sunan Nasāi, Sunan Ibnu Mājah, al-Muwatțā' Imām Mālik, Musnad Aḥmad bin Hanbal dan Sunan alDārimī. Kitab-kitab ini akan digunakan sebagai sumber primer kajian. Adapun sumber sekundernya akan digunakan kitab-kitab syarah dari kitab-kitab primer tersebut seperti Fath al-Bārī Sharaḥ Ṣahịh Bukhārī, Sharaḥ Șahịh Muslim Imām alNawāwī, 'Aun al-Ma'būd Sharah Sunan Abū Dawud, Tuhfah al-Ahwaz̄i Sharah Sunan Turmudhī, Tanwīr al-Hawālik Sharaḥ al-Muwatțā' Imām Mālik dan yang lainnya. Untuk memudahkan pelacakan data, akan digunakan dua sumber informasi baik yang bersifat manual seperti kitab al-Mu'jam al-Mufahras li Alfāz al-Hadìth karya A.J Wensinck dan Muḥammad Fuād 'Abdul Bāqi serta yang bersifat digital dari Ensiklopedi Hadis.

Adapun bila dilihat dari hasil yang ingin dicapai, maka kajian ini bersifat deskriptif. Menurut Abudin Nata, kajian deskriptif bertujuan untuk meng-

\footnotetext{
${ }^{20}$ Toshihiko Izutsu, Etika Beragama dalam Quran, terj. Mansurrdin Djoely (Jakarta: Pustaka Firdaus, 1993), h. 111-164.
} 
gambarkan secara tepat sifat-sifat suatu individu, keadaan, gejala atau kelompok tertentu, atau untuk menentukan frekuensi atau penyebaran suatu gejala dan gejala lain dalam masyarakat. Data untuk kajian seperti ini diambil dari data kualitatif. ${ }^{21}$ Dalam konteks kajian ini, ia bertujuan untuk menggambarkan suatu realitas dan peristiwa tradisi yang hidup di kalangan masyarakat Arab sebelum kedatangan Islam dan realitasnya pasca kedatangan Islam.

Selanjutnya, untuk mencari karakteristik operasional dari terma "tradisi jahiliyyah", maka untuk melacaknya akan ditelusuri kata-kata yang memiliki indikasi gambaran tradisi jahiliyyah. Kata-kata yang ditemukan dalam sebuah reportase hadith dihimpun untuk kemudian ditampilkan case by case guna melihat apa yang yang sebenarnya dibicarakan Nabi. Untuk kepentingan ini, kata-kata seperti كنّا في الجاهلية dan digunakan sebagai entri point untuk melacak tradisi jahiliyyah yang terjadi.

Penelusuran terhadap في الجاهلية ditemukan ada 380 riwayat yang tersebar dalam al-Kutub al-Tis'ah dengan rincian 71 riwayat dalam Șahịh Bukhārī, 43 riwayat dalam Șaḥịh Muslim, 19 riwayat dalam Sunan Turmūzīi, 29 riwayat dalam Sunan al-Nasai, 33 riwayat dalam Sunan Abi Daud, 15 riwayat dalam Sunan Ibni Mājah, 144 riwayat dalam Musnad Ahmad, 7 riwayat dalam alMuwatta' dan 19 riwayat dalam Sunan al-Dārimī. Adapun bila menggunakan kata كنّا في الجاهلية sebagai entri point, maka setidaknya ada 42 riwayat yang tersebar dalam al-Kutub al-Tis'ah dengan rincian ada 6 riwayat dalam Șahịh Bukhārī, 4 riwayat dalam Șạ̣ịh Muslim, 1 riwayat dalam Sunan Turmūụī, 6 riwayat dalam Sunan al-Nasai, 6 riwayat dalam Sunan Abi Daud, 2 riwayat dalam Sunan Ibni Mājah, 15 riwayat dalam Musnad Ahmmad dan 2 riwayat dalam Sunan al-Dārimī. ${ }^{22}$

\section{F. Hasil Kajian}

Setelah dilakukan telaah tradisi jahiliyah berdasarkan rekaman reportase hadis, ditemukan 49 peristiwa yang secara jelas berisi "dialog" antara Nabi sebagai representasi agama Islam pada satu sisi dengan tradisi yang ada di kalangan masyarakat Arab di sisi yang lain.

\footnotetext{
${ }^{21}$ Abudin Nata, Metodologi Studi Islam (Jakarta: Rajagrafindo, 2000), h. 125.

${ }^{22}$ Software Mausū'ah al-Hadīth al-Sharīf
} 
Dari "dialog" tersebut, ada empat hal yang menjadi temuan penting dalam kajian ini. Pertama, ada tradisi yang secara utuh diakomodir oleh Nabi dan inilah yang saya sebut dengan akomodasi total (total accomodation). Salah satu contoh berkenaan dengan hal ini sebagai terlihat dalam kasus puasa 'asyūrā' berikut ini.

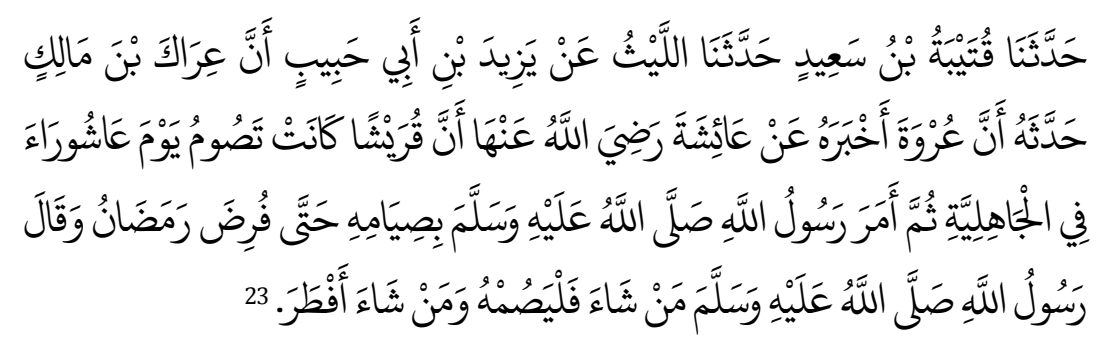

"Telah menceritakan kepada kami Qutaibah bin Sẫd, telah menceritakan kepada kami al-Laith dari Yazīd bin Abī habīb bahwasannya 'Irāk bin Mālik menceritakan kepadanya bahwa 'Urwah telah menceritakan dari 'Āisyah bahwa dahulu hari 'Āsyūrā' adalah hari yang orang-orang Quraisy pergunakan pada masa Jahiliyah untuk berpuasa. Rasūlullāh juga memerintahkan untuk berpuasa hingga datang perintah puasa ramadlan dan diwajibkan. Rasūlullāh bersabda: "Barang siapa yang ingin berpuasa 'Āsyūrā' hendaklah berpuasa, dan barangsiapa yang tidak ingin, maka tinggalkanlah." (al-Bukhārī)

Berdasarkan hadis tersebut, ijma' ulama menyepakati bahwa puasa 'Āsyūrā' hukumnya sunnah. Dalam Fatḥ al-Bārī Sharaḥ Șaḥịh Bukhārī, Ibnu Hajar al-'Asqalānī menjelaskan bahwa sebelum datangnya kewajiban puasa ramadan pada tahun kedua hijriah, Nabi juga memerintahkan umat Islam untuk berpuasa 'Āsyūrā' sebagaimana dilakukan masyarakat jahiliyyah. Mereka melakukan puasa itu juga berdasarkan warisan ajaran masa lalu. Mereka sangat mengagungkan puasa itu sehingga selain berpuasa mereka juga terbiasa melakukan penggantian penutup Ka'bah (kiswah). 'Ikrimah pernah ditanya mengenai kebiasaan puasa 'Asyurā' orang jahiliyyah: "Mereka meyakini bahwa banyak dosa yang mereka kerjakan sebelumnya akan beres dengan melakukan puasa 'Āsyūrā'

${ }^{23}$ Bukhārī dalam Kitāb al-Șaum, hadis no.1.862-1863 dan 1.760, Kitāb al-Manāqib, hadis no. 3.544, Kitāb al-H\{aj, hadis no. 1.489, Kitāb Tafsīr al-Qurān, hadis no. 4.141-4.142 dan 4.144. Lihat juga dalam Muslim, Kitāb al-Șiyām, hadis no.1.897-1.904; Turmudhī, al-Șaum, hadis no. 684; Abū Daud, al-Saum, hadis no. 2.086-2.087; Ibnu Mājah, al-Siyām, hadis no. 1.723 dan 1.727; Ahmad bin Hanbal, Bāqī Musnad al-Anșār, hadis no. 23.097, 24.131, 24.912; Mālik, al-Ṣiyam, hadis no.587; alDārimī, al-Ṣaum, hadis no. 1.695 dan 1.698. 
Kedua, ada tradisi yang total ditolak oleh Nabi dan digantikan dengan tradisi baru dan inilah yang sebut dengan penolakan total atau koreksi total (total refuse or total correction). Untuk menggambarkan hal ini bisa dilihat dalam kasus berikut ini.

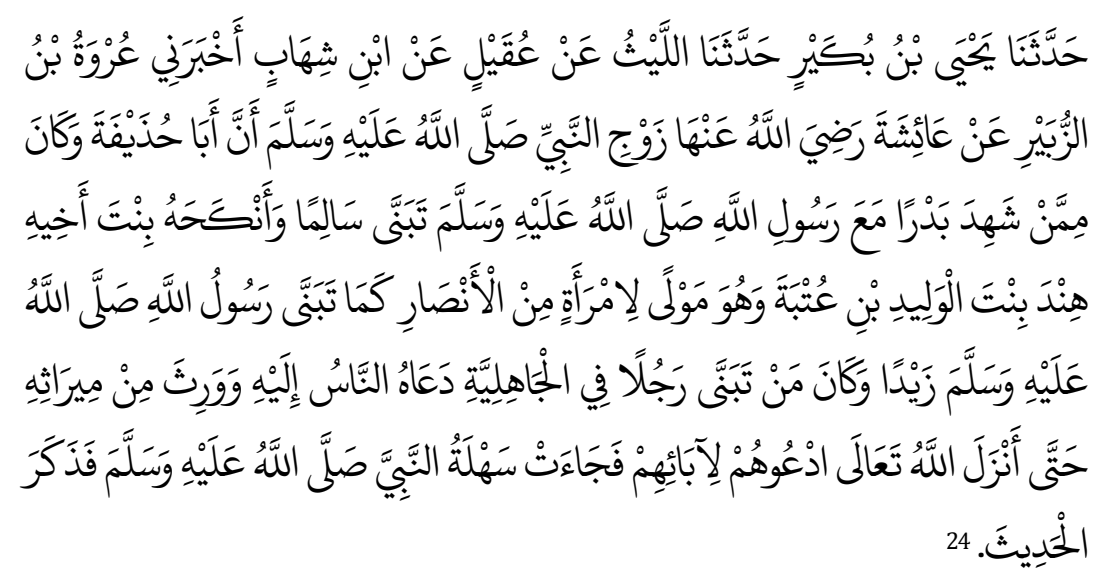

Telah menyatakan kepada kami Yahyā bin Bukair, telah menyatakan kepada kami al-Laith dari 'Uqail dari Ibnu Syihāb, telah menyatakan kepada kami 'Urwah bin Al-Zubair dari 'Āisyah, istri Nabi; "Bahwa Abū Huzaifah, salah seorang yang ikut perang Badar bersama Rasūlullāh saw menjadikan Sālim sebagai anak angkatnya lalu menikahkannya dengan putri saudaranya yang bernama Hindun binti al-Walīd bin 'Utbah. Dia adalah mantan budak seorang wanita kaum Anșār sebagaimana Rasūlullāh menjadikan Zaid sebagai anak angkat beliau. Dahulu pada zaman . Jahiliyyah, siapa yang menjadikan seseorang sebagai anak angkatnya, orang-orang memanggil sebutan ayah anak angkat itu dengan nama bapak angkatnya dan mendapatkan hak warisan dari harta warisan (ayah angkatnya) hingga Allāh Ta'ālā menurunkan firman-Nya dalam QS al-Aḥzāb ayat 5 yang artinya: "Panggilah mereka (anak angkat kalian) dengan nama bapak-bapak kandung mereka...". Kemudian Sahlah mendatangi Nabi. Lalu perawi menceritakan hadis ini. (al-Bukhārī)

${ }^{24}$ Bukhārī dalam Kitāb al-Magāzī, hadis no.3.699, al-Nikāh, hadis no. 4.698; Nasai, al-Nikāh, hadis no.3.171-3172 dan 3.267-3.271; Abū Daud, Kitāb al-Nikāh, hadis no. 1.764; Ahmad bin Hanbal, Bāqī Musnad al-Anșār, hadis no. 22.979, 24.245, 24.469, 24.724, 24.982 dan 25.125; Mālik, Kitāb alRaḍā', hadis no. 1.112; al-Dārimī, al-Nikāh, hadis no. 2.157, al-Raḍā', hadis no. 2.636-2.641; Ibnu Mājah, al-Nikāh, hadis no. 1.922. 
Dalam suatu riwayat dikemukakan bahwa para sahabat biasa memanggil Zaid bin harithah dengan sebutan "Zaid bin Muhammad". Ayat 5 dari surat alAhzāb itu turun sebagai petunjuk untuk memanggil anak angkat dengan disertai nama bapak kandungnya. ${ }^{25}$ Ayat ini mengisyaratkan dua hal penting. Pertama, Islam merevisi kebiasaan masyarakat jahiliyyah yang semua biasa memanggil nama angkat dengan menyertakan nama bapak angkatnya bahkan mewarisi orang tua angkat sebagaimana halnya anak kandung. Kedua, Islam menegaskan bahwa silsilah keturunan seseorang seharusnya tetap terlacak. Kalau sebutan anak angkat kemudian dikaitkan dengan nama orang tua angkatnya, maka sangat besar kemungkinan bahwa keturunan dari anak angkat itu kelak tidak lagi mengetahui silsilah keturunan yang sebenarnya.

Ketiga, ada tradisi yang sebagiannya diadopsi tetapi sebagian yang lain ditolak dan ini yang saya sebut sebagai akomodasi partikular (particular accomodation). Salah satu kasus yang dapat disebut disini antara lain model pernikahan yang hanya dikukuhkan satu dari empat jenis pernikahan ala jahiliyyah. Mari kita simak hadīth berikut ini.

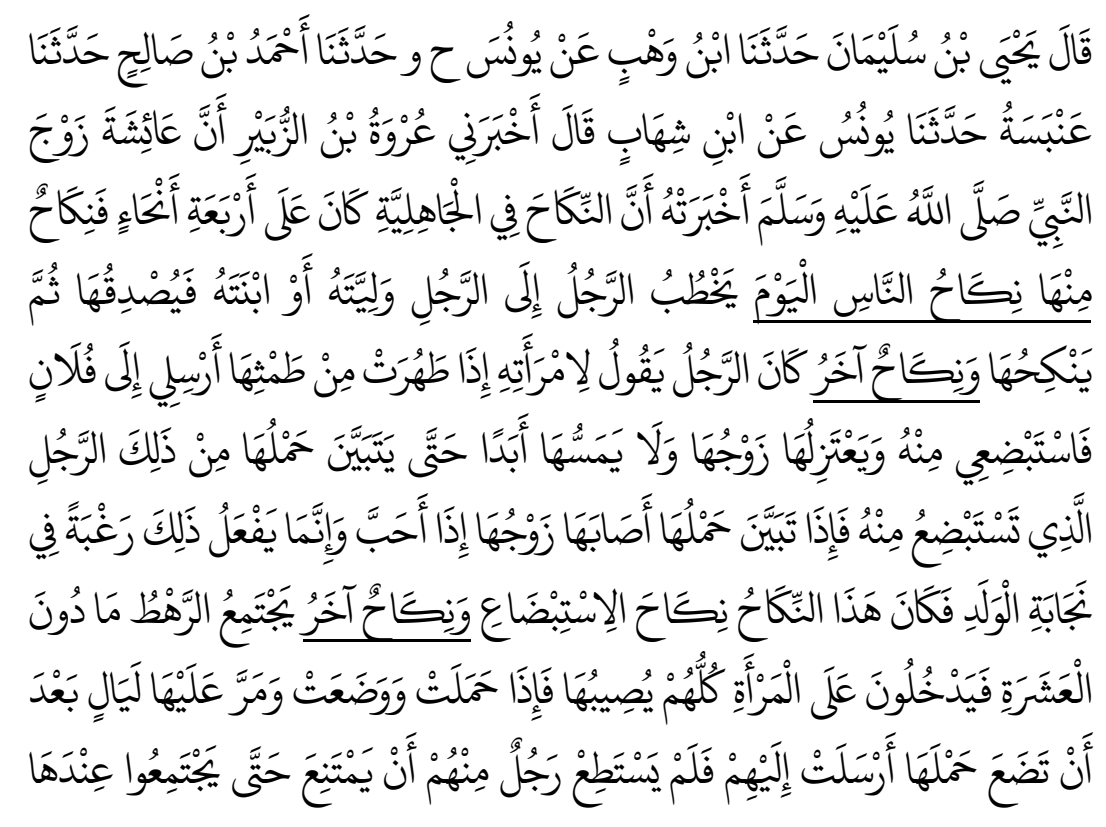

${ }^{25}$ Qamaruddin Shaleh dkk, Asbabun Nuzul (Bandung: Diponegoro, 1985), h. 393. 


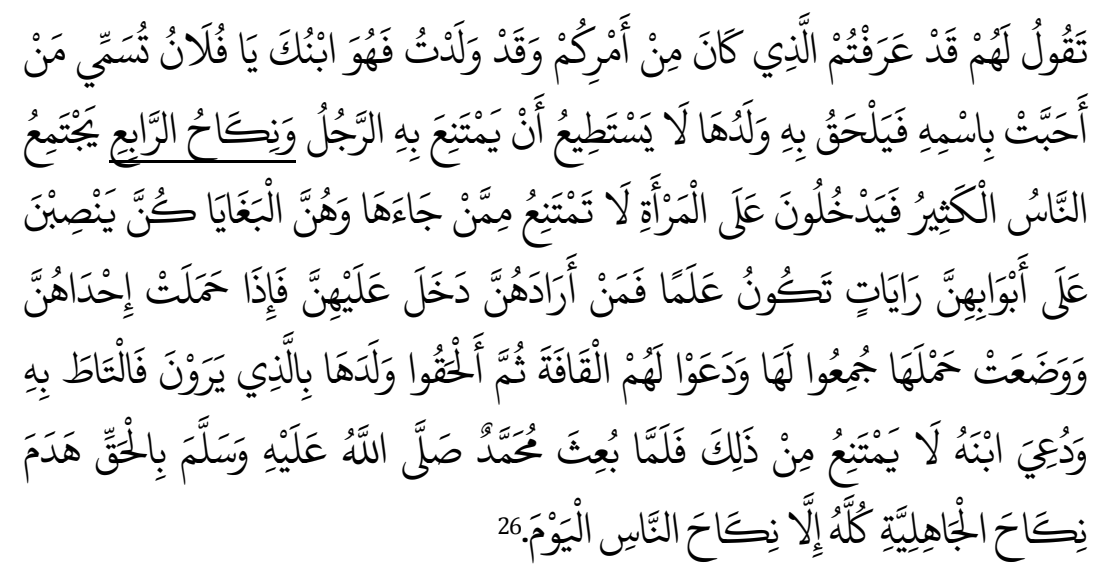

Telah berkata Yahyā bin Sulaimān, telah menyatakan kepada kami Ibnu Wahb dari Yūnus -dalam riwayat lain- dan telah menyatakan kepada kami Ahmad bin Șālih, telah menyatakan kepada kami Anbasah, telah menyatakan kepada kami Yūnus dari Ibnu Syihāb, ia berkata; telah menyatakan kepada kami 'Urwah bin Zubair bahwa 'Āisyah istri Nabi telah mengabarkan kepadanya bahwa; Sesungguhnya pada masa Jahiliyah ada empat macam bentuk pernikahan. Pertama, adalah pernikahan sebagaimana dilakukan orang-orang pada saat sekarang ini, yaitu seorang laki-laki meminang kepada wali sang wanita, kemudian memberikannya mahar lalu menikahinya. Bentuk kedua yaitu; Seorang suami berkata kepada istrinya pada saat suci (tidak haidl/subur), "Temuilah si Fulan dan bergaullah (bersetubuh) dengannya." Sementara sang suami menjauhinya sementara waktu (tidak menjima'nya) hingga benar-benar ia positif hamil dari hasil persetubuhannya dengan laki-laki itu. Dan jika dinyatakan telah positif hamil, barulah sang suami tadi menggauli istrinya bila ia suka. Ia melakukan hal itu, hanya untuk mendapatkan keturuan yang baik. Istilah nikah ini adalah Nikah al-Istibdā'. Kemudian bentuk ketiga; Sekelompok orang (kurang dari sepuluh) menggauli seorang wanita. Dan jika ternyata wanita itu hamil dan melahirkan. Maka setelah masa bersalinnya telah berlalu beberapa hari, wanita itu pun mengirimkan surat kepada sekelompok lakilaki tadi, dan tidak seorang pun yang boleh menolak. Hingga mereka pun berkumpul di tempat sang wanita itu. Lalu wanita itu pun berkata, "Kalian telah tahu apa urusan kalian yang dulu. Dan aku telah melahirnya, maka anak itu adalah anakmu wania Fulan." Yakni, wanita itu memilih nama salah seorang dari mereka yang ia sukai, dan laki-laki yang ditunjuk tidak dapat mengelak. Kemudian bentuk keempat; Orang banyak berkumpul, lalu

${ }^{26}$ Bukhārī, al-Nikāḥ, hadis no. 4.732; Abū Daud, al-țalāq, hadis no. 1.934. 
menggauli seorang wanita, dan tak seorang pun yang dapat menolak bagi yang orang yang telah menggauli sang wanita. Para wanita itu adalah wanita pelacur. Mereka menancapkan tanda pada pintu-pintu rumah mereka sebagai tanda, siapa yang ingin mereka maka ia boleh masuk dan bergaul dengan mereka. Dan ketika salah seorang dari mereka hamil, lalu melahirkan, maka mereka (orang banyak itu) pun dikumpulkan, lalu dipanggilkanlah orang yang ahli seluk beluk nasab (al-Qāfah), dan al-Qāfah inilah yang menyerahkan anak sang wanita itu kepada orang yang dianggapnya sebagai bapaknya, sehingga anak itu dipanggil sebagai anak darinya. Dan orang itu tidak bisa mengelak. Maka ketika Nabi Muhammad saw diutus dengan membawa kebenaran, beliau pun memusnahkan segala bentuk pernikahan jahiliyah, kecuali pernikahan yang dilakoni oleh orangorang hari ini. (al-Bukhārī)

Dari apa yang dikemukakan Nabi berkenaan dengan model pernikahan yang terjadi pada zaman jahiliyyah hanya ada satu model saja yang diadopsi oleh Nabi, yaitu pernikahan sebagaimana dilakukan orang Islam hingga hari ini, dimana seorang laki-laki meminang kepada wali sang wanita, kemudian memberikannya mahar lalu menikahinya. Sementara tiga model lainnya dihapuskan oleh Islam.

Keempat, ada tradisi yang secara prinsip tetap dilestarikan hanya dengan sedikit modifikasi disana-sini dan ini saya sebut sebagai penyesuaian dan modifikasi (sincronization and modification). Bagian ini termasuk bagian yang cukup mudah mendapatkan contohnya dalam hadis Nabi. Sejak dari tehnis pelaksaan sa'i, rekonstruksi pelaksanaan țawāf hingga modifikasi pelaksanaan aqīqah. Dalam kasus aqīqah dapat dilihat dalam hadis berikut ini.

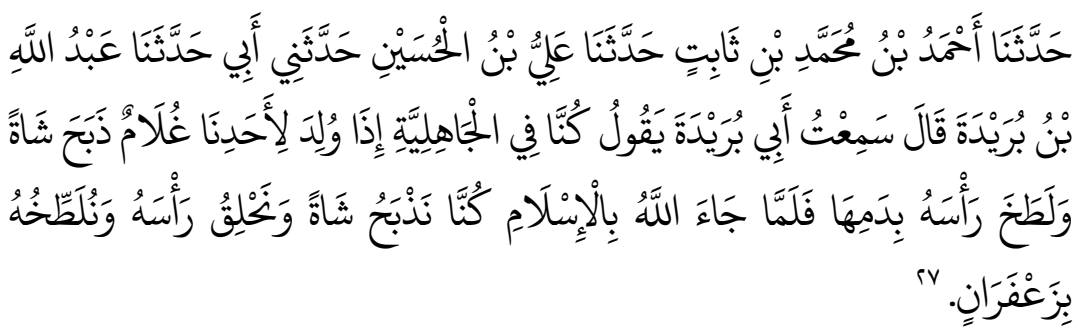

Telah menyatakan kepada kami Aḥmad bin Muhammad bin Thābit, telah menyatakan kepada kami 'Ālī bin al-Ḥusain], telah menyatakan kepada

${ }^{27} \mathrm{Abū}$ Daud, al-Ḍahāyā, hadis no. 2.460. 
kami [ayahku] telah menyatakan kepada kami 'Abdullāh bin Buraidah, ia berkata; saya mendengar ayahku yaitu Buraidah berkata; dahulu kami pada masa jahiliyah apabila salah seorang diantara kami terlahirkan anak laki-laki maka ia menyembelih seekor kambing dan melumuri kepalanya dengan darahnya. Kemudian tatkala Allāh menurunkan agama Islam maka kami menyembelih seekor kambing dan mencukur rambutnya serta melumurinya dengan minyak wangi (za'farān) . (Abū Daud)

\section{G. Kesimpulan}

Secara lebih detail, kajian ini menemukan beberapa simpulan sebagai berikut.

Pertama, tradisi yang hidup di kalangan masyarakat Arab sebelum Islam meliputi berbagai aspek: keyakinan (aqïdah) seperti penyembahan berhala, peribadatan (ibadah) seperti kasus sa'î haji, interaksi sosial (mu'āmalah) seperti superioritas komunitas tertentu (Banī Quraizah terhadap Banī Nādīir) dan pernikahan, etika (akhlāq) seperti cara berpakaian saat țawāf dan perhormatan pada janāzah.

Kedua, tradisi yang secara utuh diakomodasi (total accomodation) oleh Islam tanpa revisi antara lain: pemanfaatan pasar, puasa 'Āsyūrā' dan sumpah (qasāmah) dalam kasus pembunuhan. Sedangkan tradisi yang secara total ditolak atau total dikoreksi (total refuse or total correction) oleh Islam antara lain penyembahan berhala, menjadikan kuburan sebagai masjid, jual beli mulāmasah/munābazah/janin dalam kandungan, mendatangi peramal dan tukang tenung, status wanita menstruasi, umrah saat musim haji, wanita yang boleh dinikahi, serta berdiri dan bukan mantel saat ada jenazah lewat. Adapun tradisi yang sebagiannya diadopsi tetapi sebagian yang lain ditolak (particular accomodation) antara lain tawaf dengan telanjang, cara memulai țawāf, pembacaan ruqyah (mantera) dan poligami dengan maksimal 4 istri. Sementara tradisi yang secara prinsip tetap dilestarikan hanya dengan sedikit modifikasi disana-sini (sincronization and modification) antara lain tehnis pelaksaan sa'i, rekonstruksi pelaksanaan țawāf hingga modifikasi pelaksanaan aqīqah.

Ketiga, reportase hadis yang muncul dalam menggambarkan tradisi jahiliyyah lebih banyak diungkapkan Nabi dalam bentuk pernyataan verbal (qaulī).] 


\section{DAFTAR PUSTAKA}

Abduh, Muḥammad, Tafsīr al-Qurān al-ḥakīm al-Masyhūr bi al-Tafsīr al-Manār, Beirūt: Dār al-Fikr, t.th., Jilid IV.

AG, Muhaimin, Islam Dalam Bingkai Budaya Lokal: Potret Dari Cirebon, Ciputat: Logos Wacana Ilmu, 2001.

Amstrong, Karen, Sejarah Islam: Telaah Ringkas-Komprehensif Perkembangan Islam Sepanjang Zaman, terj. Yuliani Liputo, Bandung: Mizan, 2014.

al-'Asqalānī, Ibnu Ḥajar, Fatḥ al-Bārī, Beirūt: Dār al-Fikr, t.th.

al-Buti, Muhammad Sẫ̂̉ Ramaḍān, Sirah Nabawiyah, Analisis Ilmiyah Manhajiah, Sejarah Pergerakan Islam di Masa rasulullah, Alih Bahasa Aunur Rafiq Saleh Tamhid, Jakarta: Robbani Press, 2005.

al-Fauzān, Șāliḥ, Sharḥ Masā'il al-Jāhiliyyah, Mesir: Dār al-Bașīrah, 1997.

http://cintarosul.org/kebiasaan-baik-dalam-masyarakat-jahiliyah/. diakses pada Minggu 1 Mei 2016.

http://majalahkesehatan.com/apakah-tes-dna/

http://msubhanzamzami.wordpress.com/2010/10/18/kondisi-Arab-pra-Islamdalam-aspek-sosial-budaya-agama-ekonomi-dan-politik. diakses pada tanggal 28 April 2016.

https://sabilulilmi.wordpress.com/2013/01/17/jahiliyyah-dalam-al-quran/. diakses pada Minggu 1 Mei 2016

Izutsu, Toshihiko, Etika Beragama dalam Quran, terj. Mansurudin Djoely, Jakarta: Pustaka Firdaus, 1993.

Karim, Abdul, Sejarah Pemikiran dan Peradaban Islam, Yogyakarta: Pustaka Book Publisher, 200.

Lukito, Ratno, Pergumulan Antara Hukum Islam dan Adat di Indonesia, Jakarta: Seri INIS XXXV, INIS, 1998.

Manser, Martin H., Oxford Learner's Pocket Dictionary, New York: Oxford University Press, 1991. 
Mardikanto, Komunikasi Pembangunan, Surakarta: UNS Press. Surakarta, 1993.

Mubarakafūrī, Tuhffah al-Aḥwazi, Beirūt: Dār Ihyyā’ al-Kutub al-'Ilmiah, t.th.

Mughni, Syafiq A., Ensiklopedi Tematis Dunia Islam, Jakarta: Ichtiar Baru Van Hoeve.

Muḥammad Musțafã Azami, Studies in hadith Methodologi and Literature, Indianapolis: Islamic Teaching Centre, 1977.

Nata, Abudin, Metodologi Studi Islam, Jakarta: Rajagrafindo, 2000.

Rogers, E.M. 1983. Diffusions of Inovations, Third Edition, New York: Free Press. 1983.

Shaleh, Qamaruddin dkk, Asbabun Nuzul, Bandung: CV. Diponegoro, 1985.

Shihab, M. Quraish, Tafsìr al-Mishbāh: Pesan, Kesan dan Keserasian al-Quran, Ciputat: Lentera Hati, 2012.

Soekanto, Soerjono, Sosiologi: Suatu Pengantar, Jakarta: RajaGrafindo Persada, 1993.

Suprapto dan Fahrianoor, Komunikasi Penyuluhan dalam Teori dan Praktek, Yogyakarta: Arti Bumi Intaran, 2004.

Software Mausū'ah al-Ḥadīth al-Sharīf

Software al-Maktabah al-Shāmilah

Ṭabațaba'i, Muḥammad Ḥusein al-, al-Mīzān fi Tafsìr al-Qurān, Libanon: Muassasah al-A'lā li al-Mațbū'āt, 1991, Juz. V. 
